\title{
THREE YEARS OF THE TRANSPORTATION ACT
}

\author{
E. G. Buckrand
}

The Transportation Act, I920, ${ }^{1}$ became a law on February 28 th, I920. It introduced into the federal legislation a new railroad policy. Theretofore the efforts of Congress had been directed mainly to the prevention of abuses, particularly those arising from excessive or discriminatory rates. The Act sought to ensure, also, adequate transportation service-hence the language in the Act, "to enable the carriers properly to meet the transportation needs of the public,"2 to "give due consideration .... to the transportation needs of the country, and the necessity .... of enlarging .... [transportation] facilities,"3 to "best meet the emergency and serve the public interest," 4 to "best promote the service in the interest of the public and the commerce of the people"5 so "that the public interest will be promoted." Among the provisions indicating the new policy are those relating to: I, the consolidation of the railroads into a limited number of systems; II, the establishment of railroad labor and adjustment boards; and III, the securing a fair return on the capital devoted to the transportation service. These are the principal innovations, and are the three with which this article will deal.

I

The provisions of the act for the consolidation of the railways into a limited number of systems was a compromise between two opinions, one of which opposed any legislation, the other of which urged compulsory consolidations. The former would have left the anti-trust laws in full force and effect, the latter would have attempted to compel consolidations whether or not the carriers to be consolidated were willing that such consolidations should be made. The Act provided that the Commission should prepare and adopt a plan for the consolidation of the railway properties of the continental United States into a limited number of systems in which competition should be preserved as fully as possible and wherever practicable existing routes and channels of trade and commerce should be maintained. The competitive systems so established should be so related to each other that the values of their respective properties through which the service was rendered should be the same so far as practicable, so that the systems could employ uniform rates in the movement of competitive traffic, and under efficient management earn substantially the same rate of return upon the value of their respective railway properties. To this end the Commission employed Professor W. Z. Ripley, of Harvard University, to make a study of the

$\begin{array}{lll}{ }^{1} 4 \mathrm{I} \text { Stat. at L. } 456 . & { }^{3} \text { Ibid. } 488 . & { }^{5} \text { Ibid. } 477 . \\ { }^{2} \text { Ibid. } 468,49 \mathrm{x} . & & \end{array}$


existing railway systems of the United States and to report what consolidations ought to be made. Professor Ripley, after an extended investigation, made a report to the Commission, which on August 3, I92x, issued the tentative plan dividing the country into nineteen systems. ${ }^{7}$ After the tentative plan had been agreed upon, the Commission, pursuant to the requirements of the Act, gave publicity to the same and notice to each of the Governors of each of the states in which any system was located, with the intention to hear all who might file or ' present objections thereto. It is the purpose of the Act that after the hearings shall have been completed the Commission shall adopt a final plan for such consolidations, and publish the same, but it may at any time thereafter reopen the subject for such changes or modifications as in its judgment shall promote the public interest. When the final plan has been adopted consolidations may be provided for in harmony with the plan, and the carriers affected are relieved from the prohibition of the anti-trust laws, and of all other restraints or prohibitions by law, state or federal, in so far as may be necessary to enable them to complete the consolidations and operate under the plan. The Commission has held hearings generally covering the southeastern lines. At these hearings considerable opposition has been displayed to the proposed consolidations, particularly between existing competitive systems. More recently the Commission has considered the consolidations of the lines west of the Mississippi, and particularly those embracing the northwestern lines. On the first of March a plan for the consolidation of the railway systems west of Chicago into four great systems was brought forth by Mr. Hale Holden, President of the Chicago, Burlington and Quincy, in which he advocated the establishment of four systems, each operating more than 30,000 miles of lines, with property investments of approximately $\$ 2,000,000,000$ to each group. In his plan each of the systems would have access to the Great Lakes, the Gulf of Mexico, and the Pacific Coast. He stated that the Burlington, the Northern Pacific, the Great Northern, and the Colorado and Southwestern roads were ready to consolidate if the authority of the Commission was given, and he urged that this permission be granted so that a beginning could be made in carrying out the consolidation provisions of the Act. The four main systems were designated, respectively, as the Burlington, the Union Pacific, the Santa Fe, and the Southern Pacific, and Mr. Holden showed that in geographical extent these systems would not be materially more widely extended than several of the systems proposed by the Commission. 8

\footnotetext{
7 Some of these systems-such as number 3, the Baltimore and Ohio; number 7 , the New England; and number 7a, the New England and Great Lakes-overlapped each other, and were obviously to some extent in the alternative.

See account of the plan in N. Y. TIMres of March 2, 1923, p. I, col. I.

It will be noted that Mr. Holden spoke only for the lines with which the Burlington was connected or affiliated, but the development is significant in that it indicates that there may be a tendency on the part of these carriers voluntarily
} 
In New England a characteristically different treatment has been accorded the tentative plans offered for consolidation of the New England railroads. Three alternative plans were offered by the Commission:

(I) System No. 7, including all of the New England roads, excepting the Central Vermont, the Rutland, and the Boston \& Albany (the latter being regarded as a New York Central line), the Lehigh and 'Hudson, and the Lehigh and New England.

(2) System No. 7a, New England-Great Lakes, being the same as the one just described, but including the Delaware \& Hudson, the Ulster and Delaware, the Delaware, the Lackawanna \& Western, the Buffalo, Rochester \& Pittsburgh, the Pittsburgh \& Shawmut, and the Pittsburgh, Shawmut \& Northern.

(3) System No. 3, which includes the Baltimore \& Ohio, the Reading System, the Cincinnati, Indianapolis \& Western, the Chicago, Indianapolis \& Louisville, the New Haven System, the Lehigh \& New England, and the Lehigh and Hudson. ${ }^{\circ}$

When the tentative plans were published by the Commission, and the Governors as required by the Act were notified, they under the invitation of Governor Cox of Massachusetts appointed in each of the six New England States an advisory committee of five to investigate railroad conditions in New England and to report to the Governors what position they should take with regard to the tentative plans or to make

to follow the suggestions of the act in creating systems, each of which shall approximate the same amount of operating mileage, to wit, between 30,000 and 35,000 miles, of investment in road and equipment, to wit, between $\$ 2,000,000,000$, and $\$ 2,300,000,000$, although the net railway operating income varies from $\$ 70,000$,000 to $\$ 95,000,000$, and the per cent of return in the year I922 from 3.II to 4.22.

${ }^{\circ}$ Before the tentative plans were published experts were at work investigating two possibilities, - one a plan for an exclusively New England consolidation, the other for a plan involving the consolidation of the northern New England roads with either the New York Central or the Delaware \& Hudson and the southern New England roads with the Pennsylvania or the Baltimore \& Ohio. Mr. John E. Oldham, of the firm of Merrels \& Oldham, presented a plan involving a sort of holding company whereby each of the principal roads west of the Hudson should invest in the New England roads and operate them as terminals for their respective properties, each of the lines west of the Hudson having equal operating and traffic rights in all of the lines east of the Hudson. Mr. Oldham argued that upon the statistics of past performance the New England roads were unable to sustain themselves, and that the New England consolidation would only be an assembling of financially weak roads without the ability on the part of any of them or all of them combined to make an income which would establish the credit sufficient to enable them to provide for the necessary additions and betterments to render adequate service in the future. Those who favor the New England consolidation refer to the obligation lying upon the Commission to fix rates so that the carriers by groups shall earn as nearly as may be a fair return upon the value of the properties devoted to the service of transportation, and have argued that where within groups any carrier which is of importance to the public is not receiving a fair return, the Commission through its power to prescribe divisions may allot to such carrier sufficient to enable it to earn a fair return. 
suggestions for any new plans which the investigation might indicate to be desirable. The six Committees joined forces and created a joint committee under the chairmanship of Mr. James J. Storrow, of Boston, also the Chairman of the Massachusetts Committee. This joint New England committee began hearings early in the winter and has been conducting'them ever since. The joint committee is not limiting its efforts merely to studying consolidations of railroads, but is taking the opportunity to investigate every activity of each of the companies.

\section{II}

The Transportation Act created ${ }^{10}$ a Railroad Labor Board consisting of nine members, three from the labor group representing the employees and subordinate officials of the carriers, three from the management group representing the carriers, and three from the public group representing the public. The Act also provides ${ }^{11}$ for the establishment of railroad boards of adjustment by agreement between any carrier, group of carriers or the carriers as a whole, or organizations or groups of organizations thereof, and for hearings and decisions by such boards of adjustment upon petition for adjustment of disputes involving only grievances, rules, or working conditions which have not been decided as between the officers on the one hand, and employees and subordinate offcials on the other, whose duty is declared to be "to exert every reasonable effort .... to avoid any interruption in the operation of any carrier."12 The decision of the Board in the case of wage disputes requires the concurrence of five members, of whom the member of the Public Group must be one. ${ }^{13}$ All decisions of the Labor Board shall be entered upon its records, immediately communicated to the parties in dispute, and given such further publicity in such manner as the Labor Board may determine. ${ }^{14}$ These decisions shall establish standards of wages and working conditions which in the opinion of the Board are just and reasonable. ${ }^{15}$

Pursuant to this authority, the Labor Board has in the last three years increased wages $\$ 595,384,342.00$, and decreased wages $\$ 5 \mathrm{I} 3,844,4 \mathrm{I} 8.00$, leaving a net increase of $\$ 81,539,924.00$, or 3.2 per cent, ${ }^{18}$ the effect of which upon the operating expenses of the carriers will be shown hereafter. ${ }^{17}$ In the course of the hearings before the Labor Board and decisions thereunder, questions arose as to the authority of the Labor Board to require carriers or employees to abide by its decisions. The employees complained that some of the carriers, after the increase in wages to the shopcrafts, were "contracting out" their repair work, and

\footnotetext{
${ }^{10}$ Sipra note I, at p. 470. $\quad{ }^{13}$ Ibid. $47 \mathrm{I}$.

I1 Ibid. 469 . $\quad{ }^{14}$ Ibid. 47 I.

${ }^{12}$ Ibid. 469.

${ }^{16}$ Report No. 3, U. S. Railroad Labor Board, October, I92r.

${ }^{17}$ Infra, at p. 668.
} 
in a few cases it was shown that the carriers, taking advantage of the lower price of labor in outside industries, had turned over their repair - shops to other concerns, who thereupon either discharged the former railroad employees and rehired them at a lower rate, or hired other employees at the going rate of wages. This practice was not generally countenanced by the railroads of the country and was indulged in by comparatively few. It was assigned, however, as one of the reasons for the refusal of the shopcraft employes to abide by the decision ${ }^{18}$ of the Labor Board decreasing by ten per cent the wages of the shopcrafts, effective July I, I922, and it was this decrease which was the cause of the present shopcrafts strike.

In the meantime the Pennsylvania Railroad Company endeavored to establish its right to deal with its own employees through representatives who were the employees of the Pennsylvania Railroad Company, and to refuse to deal with representatives who were not such employees. The dispute, which was decided by the United States Supreme Court in February, this year, ${ }^{19}$ arose in May, 192I, at which time the officers of the Federated Shopcrafts of the Pennsylyania System (a labor union of employees of that system engaged in shop work, and affiliated with the American Federation of Labor) met the representatives of the Pennsylvania Railroad Company. They said they represented a majority of the employees of the Pennsylvania System in those crafts and were prepared to confer and agree upon rules and working conditions. The Pennsylvania representatives refused to confer with the Federation for lack of proof that it did represent such a majority, and said they would send out a form of ballot to their employees asking them to designate thereon their representatives. In the previous April, the Board had rendered a decision, and accompanied it with a statement of principles which it intended to follow in the consideration and settlement of disputes between the carriers and employees, the only two important ones for present purposes being the following : ${ }^{20}$

"The right of such lawful organization [of employees] to act toward lawful objects through representatives of its own choice, whether employees of a particular carrier or otherwise, shall be agreed to by management."

"The majority of any craft or class of employees shall have the right to determine what organization shall represent members of such craft or class. Such organization shall have the right to make an agreement which shall apply to all employees in such craft or class. No such agreement shall infringe, however, upon the right of employees not members of the organization representing the majority to present grievances either in person or by representatives of their own choice."

\footnotetext{
${ }^{18}$ U. S. Railroad Labor Board, Decision No. I036, effective July I, I922.

${ }^{19}$ Pennsylvania Ry. v. United States Railroad Labor Board (Feb. 19, I923) Oct. T. I922, No. 585. The facts in the case may be found in the statement by Mr. Chief Justice Taft, pp. r-6.

${ }^{20}$ Quoted ibid. at p. 3.
} 
The Federation officers objected to the proposed ballot because it was not in accordance with these principles, in that it made no provision for representation of employees by an organization, but specified that those selected must be natural persons, and such only as were employees of the Pennsylvania Company, and also because it required that the representatives of the employees should be selected regionally rather than from the whole system. The result was that the Company and the Federation each sent out ballots. The Federation then filed a complaint under Section 307 of the Transportation Act, ${ }^{21}$ against the Pennsylvania Company, complaining, on behalf of its members directly interested, of the Company's course in respect to the ballots. The Company appeared, a hearing was had, and the Board decided that neither of the ballots sent out by the parties was proper; that representatives so chosen were not proper representatives; and that rules and working conditions agreed upon by them would be void. It further appeared that the votes cast on the Company's ballots were only a little more than 3,000 out of more than 33,000 employees entitled to vote. The Federation had advised its members not to vote on the Company's ballots. What the result was in the vote of the Federation ballots did not appear. The persons chosen by the 3,000 votes on the Company's ballots conferred with the Pennsylvania Company's representatives and agreed upon rules and working conditions. The Board in its decision ordered a new election for which rules were prescribed and a form of ballot was specified, on which labor organizations as well as individuals could be voted for as representatives at the option of the employee. The Company asked the Board to vacate this decision, but the Board declined to do so, but said that it would allow the Company to be heard on the question of the ratification of its shopcraft rules by representatives of the crafts concerned when fairly selected. The Board thereupon proceeded in accordance with the provisions of Section $3^{I} 3^{22}$ of the Act to prepare a statement that the Pennsylvania Railroad Company had violated its decision and was preparing to make public this alleged violation. The Pennsylvania Railroad Company asked for an injunction against the threatened official publication, which the District Court granted. The Labor Board appealed to the Circuit Court of Appeals, which reversed the decree and directed the dismissal of the bill. The Pennsylvania Railroad Company appealed from the Circuit Court of Appeals' decree to the United States Supreme Court, and it was upon this issue that the decision was rendered on February igth.

Mr. Chief Justice Taft, delivered the unanimous opinion of the Court. In the course of his opinion he said :23

\footnotetext{
${ }^{21}$ Supra note I, at p. 470.

Ibid. at p. 473 .

${ }^{23}$ Penusylvania Ry. v. United States Railroad Labor Board, supra note I9, at pp. 6 and 7.
} 
"It is evident from a review of Title III of the Transportation Act of I920 that Congress deems it of the highest public interest to prevent the interruption of interstate commerce by labor disputes and strikes and that its plan is to encourage settlement without strikes, first by conference between the parties; failing that, by reference to adjustment boards of the parties' own choosing, and if this is ineffective, by a full hearing before a National Board appointed by the President, upon which are an equal number of representatives of the Carrier Group, the Labor Group, and the Public. The decisions of the Labor Board are not to be enforced by process. The only sanction of its decision is to be the force of public opinion invoked by the fairness of a full hearing, the intrinsic justice of the conclusion, strengthened by the official prestige of the Board, and the full publication of the violation of such decision by any party to the proceeding. The evident thought of Congress in these provisions is that the economic interest of every member of the Public in the undisturbed flow of interstate commerce and the acute inconvenience to which all must be subjected by an interruption caused by a serious and widespread labor dispute, fastens public attention closely on all the circumstances of the controversy and arouses public criticism of the side thought to be at fault. The function of the Labor Board is to direct that public criticism against the party who, it thinks, justly deserves it."

The Court goes on to say: ${ }^{24}$

"The only question between the Company and the Federation is whether the membership of the latter includes a majority of the Company's employees who are interested. But it is said that the Federation is a labor union affiliated with the American Federation of Labor and that the phrase 'organization of employees' used in the Act was not intended by Congress to include labor unions. We find nothing in the Act to impose any such limitation if the organization in other respects fulfills the description of the Act. Congress has frequently recognized the legality of labor unions .... and no reason suggests itself why such an association, if its membership is properly inclusive, may not be regarded as among the organizations of employees referred to in this legislation."

It was also urged by the Pennsylvania Company that the question who may represent the employees is not within the jurisdiction of the Labor Board to decide; that these representatives must be determined before the conferences are held; that the jurisdiction of the Labor Board does not begin until after these conferences are held; and that the representatives who can make application are the representatives engaged in the conference. The Court says" that, "such a construction would give either side an easy opportunity to defeat the operation of the Act and to prevent the Labor Board from considering any dispute. It would tend to make the Act unworkable. If the Board has jurisdiction to hear representatives of the employees, it must of necessity have the power to determine who are proper representatives of the employees. That is a condition precedent to its effective exercise of jurisdiction at all. One

${ }^{24}$ Ibid. at p. 8.

${ }^{25} \mathrm{Ibid}$. at p. 9. 
of its specific powers conferred by Section 308 is 'to make regulations necessary for the efficient execution of the functions vested in it by this title.' This must include the authority to determine who are proper representatives of the employees and to make reasonable rules for ascertaining the will of the employees. ..." The Court again refers to the fact that historically, the question who may be representatives of employees, not only before the Board, but in conferences and elsewhere, is and always has been one of the most important questions involved in the operation of a railroad. The purpose of Congress to promote harmonious relations between carriers and their employees is seen in every section of the Act, and Congress must therefore have intended to include the procedure for determining who should be representatives of employees as a proper subject matter to be considered by the Board. "The Act is to be liberally construed to effect the manifest effort of Congress to compose differences between railroad companies and their employees, and it would not help this effort, to exclude from the lawful consideration of the Labor Board a question which has so often seriously affected the relations between the companies and their employees in the past and is often encountered on the very threshold of controversies between them." 26

To the claim by the counsel of the Company, that it has the right to deal with individual representatives of its employees and that this is an inherent right which cannot be constitutionally taken from it, and to the claim of the employees, or at least those who are members of the labor unions, that they have a lawful right to select their own representatives, and that it is not within the right of the Company to restrict them in their selection to employees of the Company or to forbid selection of officers of their labor unions qualified to deal with and protect their interests, the court said that the statute does not deprive either side of the rights claimed, but it used this significant language $:^{27}$

The law "was not enacted to provide a tribunal to determine what were the legal rights and obligations of railway employers and employees or to enforce or protect them. Courts can do that. The Labor Board was created to decide how the parties ought to exercise their legal rights so as to enable them to coopperate in running the railroad. It was to reach a fair compromise between the parties without regard to the legal rights upon which each side might insist in a court of law. The Board is to act as a Board of Arbitration. It is to give expression to its view of the moral obligation of each side as members of society to agree upon a basis for coöperation in the work of running the railroad in the public interest. The only limitation upon the Board's decisions is that they should establish a standard of conditions, which, in its opinion, is just and reasonable. The jurisdiction of the Board to direct the parties to do what it deems they should do is not to be limited by their constitutional or legal right to refuse to do it. Under the Act there is no constraint upon them to do what the Board decides they should do except the moral constraint, already mentioned, of publication of its decisions.

${ }^{20}$ Ibid. at p. Io.

${ }^{27}$ Ibid. at pp. ro and II. 
"It is not for this or any other court to pass upon the correctness of the conclusion of the Labor Board if it keeps within the jurisdiction thus assigned to it by the statute. The statute does not require the Railway Company to recognize or to deal with, or confer with labor unions. It does not require employees to deal with their employers through their fellow employees. But we think it does vest the Labor Board with power to decide how such representatives ought to be chosen with a view to securing a satisfactory coöperation and leaves it to the two sides to accept or reject the decision. The statute provides the machinery for conferences, the hearings, the decisions and the moral sanction. The Labor Board must comply with the requirements of the statute; but having thus complied, it is not in its reasonings and conclusions limited as a court is limited to a consideration of the legal rights of the parties."

The Court concludes: $:^{28}$

"It is not for us to express any opinion upon the merits of these principles and decisions announced by the Board. All that we may do in this case is to hold, as we do, that they were within the lawful function of the Board to render, and not being compulsory, violate no legal or equitable right of the complaining company.

"For this reason, we think that the District Court was wrong in enjoining the Labor Board from proceeding to entertain further jurisdiction and from publishing its opinions, and that the Court of Appeals was right in reversing the District Court and in directing a dismissal of the bill."

This is the first time that the United States Supreme Court has construed the powers of the Labor Board under the Transportation Act, and in effect establishes it merely as a body of arbitrators, whose decisions have no force excepting that of public opinion.

\section{III}

More important than the provisions relating to consolidations of railroads into a limited number of systems, or the establishment of railroad labor and adjustment boards, are the provisions ${ }^{29}$ of the Act imposing upon the Interstate Commerce Commission the obligation to preserve for the nation substantially the whole transportation system by establishing rates which will yield a fair return upon the value of the property held for and used in the service of transportation. It will be remembered that for the first two years of the Act, the Commission determined that six per cent would be the fair return. ${ }^{30}$ This was reduced by one-quarter of one per cent after March Ist, $1922,{ }^{31}$ at which figure it now remains. The return is based upon the aggregate value

${ }^{2 s}$ Ibid. at pp. II and I2.

${ }^{29}$ Supra note I, at p. $48 \mathrm{I}$ et seq.

${ }^{30}$ Ex parte 74, Increased Rates, I920 (July 29, I920) 58 I. C. C. 220.

${ }^{31}$ Reduced Rates, 1922 (May I6, I922) 68 I. C. C. 676. 
of the railway property held for and used in the service of transportation, and represents the amount which will remain after the payment of operating expenses (including those for maintenance of way, structures, and equipment). The management must be honest, efficient, and economical. This is nothing more than the common-law right of each carrier to be permitted to earn as a condition of service a reasonable return upon the value of its property. But before the Transportation Act, it had been difficult, if not impossible, for any carrier to prove that the unwillingness of the Commission to permit an increase in a rate, or its insistence upon the reduction of a rate, did in and of itself deprive the carrier of such return and so confiscate its property; and so, although carriers had in many instances been morally certain that decisions of the Commission amounted to confiscation, they seldom tried out the issue. The Transportation Act reversed the position of the Commission. Instead of being a restrictive body it had to become a constructive body, and the mandate was laid upon it to fix rates so that the properties of the carriers should, as nearly as may be, earn a fair return.

The first important decision of the Commission under the Act was in Ex Parte 74, Increased Rates, I920, ${ }^{32}$ in which, after an extended hearing, the Commission, in the absence of final values found under the Valuation Act, fixed the total value of the railroads at $\$ 18,900,000,000$, and the value of those in the Eastern group at $\$ 8,800,000,000$. It established four groups and increased the freight rates as follows: Eastern Group, 40 per cent; Southern Group, 25 per cent; Western Group, 35 per cent; Mountain-Pacific Group, 25 per cent, and increased passenger rates 20 per cent in all groups. It has made two general decreases, one of the hay and grain rates, ${ }^{33}$ effective January I, I922, Io per cent, and the other a general decrease of Io per cent in all groups, ${ }^{34}$ effective July I, I922.

The effect of these adjustments of rates by the Interstate Commerce Commission, and the adjustments of wages by the Railroad Labor Board, is seen in the following percentage of revenues and expenses in

\footnotetext{
${ }^{32}$ Silpra'note 30.

${ }^{33}$ Rates on Grain, Grain Products, and Hay (Oct. 20, I92I) 64 I. C. C. 85.

"Reduced Rates, 1922, supra note 3I, at p. 734 et seq. Effective July I, I922, it made a general reduction of ro per cent on all rates increased by authority of Ex Parte 74, supra note 30. Prior to that, the Interstate Commerce Commission had ordered (I92I, 64 I. C. C. 85 , IOr) a general reduction ranging from to to 22 per cent with respect to carload rates on grain, grain products, and hay in the western and Mountain-Pacific groups, which became effective during January, I922, and upon its recommendation (I92I, 63 I. C. C. I07, II8) rates on live stock in the same groups in excess of 50 cents per Ioo pounds had been reduced 20 per cent, but not below 50 cents, in October, r92I. Practically all other carload rates upon products of the farm, garden, orchard, and range throughout the country were reduced ro per cent in July, r922. All of these reduced rates, other than those on grain, grain products and hay in the Western and Mountain-Pacific groups expired by tariff limitation on June 30, I922. (See also (I922) 68 I. C. C. $676,703$.
} 
the years I920, I92x, and I922, and the percentage of return upon the value of the property as fixed by the Commission: ${ }^{35}$

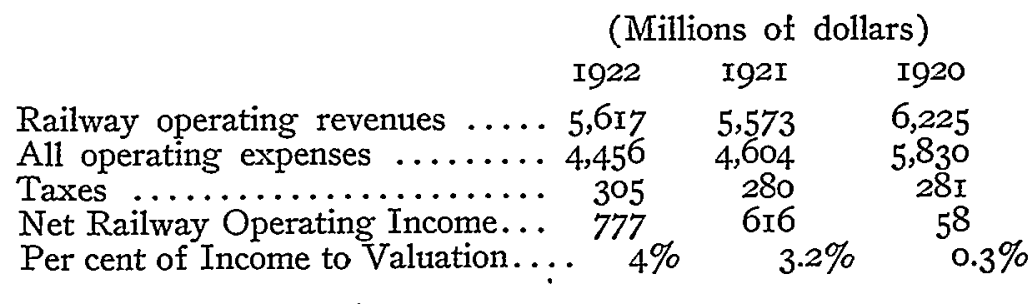

These decisions of the Commission have given rise to considerable litigation. Five cases ${ }^{36}$ dealing with this part of the Act have come before the United States Supreme Court.

The first case was that of North Dakota v. Chicago \& North Western $R y{ }^{37}$ In that case the State of North Dakota attempted, by an original suit in the Supreme Court, to restrain the Chicago \& North Western Railway Company and four other railroads from applying an order of the Interstate Commerce Commission increasing intrastate rates in North Dakota until the Supreme Court of the United States could review the decision of the Commission and pass upon the constitutional questions concerning it. This case was watched by the Bar with much interest, not only because it was the first test of the power of Congress over intrastate rates, but also because of the novel procedure by original suit in the Supreme Court rather than by the method prescribed by the Judicial Code. ${ }^{38}$ The Court in this case declined to pass upon the power of Congress over intrastate rates, and dismissed the bill because the

${ }^{3}$ Bureau of Statistics, I. C. C. "Results of Railroad Operation in I922," issued February 23, r922.

${ }^{36}$ These five cases are discussed or referred to in the remaining part of the present article. The other cases of importance that deal with the Transportation Act, 1920, are Pennsylvania Ry. v. Labor Board, supra note 19, already discussed in this article; and Texas v. Eastern Texas Ry. (I922) 258 U. S. 204, 42 Sup. Ct. $28 \mathrm{I}$, which construed paragraphs I8, I9, and 20 of sec. I of the Act to Regulate Commerce-which paragraphs were added by sec. 402 of the Transpdrtation Act (4I Stat. at L. 456, 477) -regulating the extension, construction, and abandonment of lines of railroad, "as not clothing the Commission with any authority over the discontinuance of the purely intrastate business of a road whose situation and ownership, as here, are such that interstate and foreign commerce will not be burdened or affected by a continuance of that business." (258 U. S. at p. 218,42 Sup. Ct. at p. 284.)

${ }^{37}$ (Jan. 23, I922) 257 U. S. 485, 42 Sup. Ct. 170, aff'd. in Texas v. Interstate Commerce Com. (I922) 258 U. S. 158, 42 Sup. Ct. 26 I.

ss "The argument that we shall consider is that the suit is one to set aside or suspend the order of the Commission, Illinois Central R. R. Co. v. State Public Utilities Commission, 245 U. S. 493 ; that therefore by §2II of the Judicial Code the United States must be made a party, and that the United States has consented to be sued only in the District Court, where such suits are required to be brought. Judicial Code, \$208. Act of October 22, 19r3, C. 32, 38 Stat. 219." Ibid. at p. 489, 42 Sup. Ct. at pp. I70-I7r. 
state had not followed the provisions of the Judicial Code. The Court said, ${ }^{39}$ by Mr. Justice Holmes :

"The main contention of the State is that if in the opinion of the Court it has a substantial right that is infringed by what the defendants are doing Congress neither can take that right away nor prevent the State from proceeding in this Court for such remedy as law or equity may afford. ${ }^{40}$ But if these premises were granted, it would not follow that the bill should be maintained. It is a proceeding in equity in which the requirements of complete justice and of public policy must be taken into account. When they are considered it seems to us pretty clear that the State should be remitted to the remedy offered by the statutes-a suit in the District Court in which the United States is made a party. Complete justice requires that the railroads should not be subjected to the risk of two irreconcilable commands-that of the Interstate Commerce Commission enforced by a decree on the one side and that of this Court on the other. The decision in this case although an authority would not be res judicata, and the Commission would not be concluded from rearguing the whole matter."

It will be observed that neither the Interstate Commerce Commission nor the United States was made a party to this action, although the Judicial Code requires the action to be brought against the United States and notice to be given to the Interstate Commerce Commission and to the Attorney General of the United States. ${ }^{41}$ Commenting upon this, the Court concluded:

"For the reasons that we have indicated it is equitable that a decree should not be entered except in such form as to bind the Interstate Commerce Commission and the United States and therefore, this bill must be dismissed. The right of the State is sufficiently protected by its right to appeal from the decision of the District Court."

The next case that arose was that of the Ry. Commission of Wisconsin v. Chicago, Burlington \& Quincy $R \mathrm{y}^{.2}$ The Interstate Commerce Commission, in Ex Parte $74{ }^{43}$ ordered an increase to the carriers in the group of which the Wisconsin carriers were a part, of 35 per cent in interstate, freight rates and 20 per cent in interstate passenger rates and excess baggage charges, and a surcharge upon passengers in sleeping cars amounting to 50 per cent of the charge for space in such cars to accrue to the rail carriers. Thereupon the carriers applied to the Wisconsin Railroad Commission for corresponding increases in intrastate rates. The state commission granted an increase in intrastate freight rates of 35 per cent, but denied any in intrastate passenger fares

\footnotetext{
${ }^{30}$ Ibid. 490, 42 Sup. Ct. I7I.

${ }^{40}$ In all Cases ... . in which a State shall be Party, the supreme Court shall have original Jurisdiction." U. S. Const. (I789) art. 3, sec. 2.

${ }^{4} C f$. extract from opinion quoted in note 38 , supra.

(Feb. 27, 1922) 257 U. S. 563, 42 Sup. Ct. 232. For a discussion of this case see Comiments (I922) 3I Yale Law Journat, 870.

* Supra note 30 .
} 
and charges on the sole ground that a state statute prescribed a maximum for passengers of two cents a mile. The Interstate Commerce Commission began a proceeding to determine whether this amounted to undue and unreasonable discrimination against interstate commerce, which proceeding was entitled $W$ isconsin Passenger Fares. ${ }^{44}$ The Interstate Commerce Commission found ${ }^{45}$

"that all of the respondent carriers of Wisconsin transported both intrastate and interstate passengers on the same train, with the same service and accommodations; that the state passenger paying the lower rate rode on the same train, in the same car, and perhaps in the same seat with the interstate passenger who paid the higher rate; that the circumstances and conditions were substantially similar for interstate as for intrastate passenger service in Wisconsin; that travelers destined to, or coming from, points outside the State found it cheaper to pay the intrastate fare within Wisconsin and the interstate fare beyond the border than to pay the through interstate fare; that undue preference and prejudice were shown by the falling off of sales of tickets from border line points in Minnesota and Michigan to stations in Wisconsin, and by a marked increase in sales of local tickets from corresponding border line points in Wisconsin to stations in Wisconsin; ....

"The Commission further found that the fare necessary to fulfill the requirement as to net income of this interstate railroad group under \$I 5a was 3.6 cents per mile, and that this was reasonable, that the direct revenue loss to the Wisconsin carriers, due to their failure to secure the 20 per cent. increase in intrastate fares, would approximate $\$ 2,400,000$ per year if the 3 -cent fare fixed by the President under federal war control, were continued, and $\$ 6,000,000$ per year if the 2-cent fare named in the state statute should become effective.

"The Commission found that there was undue, unreasonable and unjust discrimination against persons travelling in interstate commerce and against interstate commerce as a whole; and ordered that the undue discrimination should be removed by increases in all intrastate passenger fares and excess baggage charges and by surcharges corresponding with the increases and surcharges ordered in interstate business. . .

"The carriers filed bills in equity .... in the District Court to enjoin the State Railroad Commission and other state officials from interfering with the maintenance of the fares thus ordered and published."

An interlocutory injunction was granted after hearing before three judges.

After disposing of a preliminary question the Court, speaking through Mr. Chief Justice Taft, proceeds to the consideration of the main question which was, ${ }^{46}$ "Are these intrastate fares an undue discrimination against interstate commerce as a whole which it is the duty of the Cammission to remove?" The Court recites the history of the Interstate Commerce Act from its passage in 1887 down to and including the Mann-Elkins amendment of I9Io, when the Commission was for the

44 (I920) 59 I. C. C. 39 I.

4s Statement in Ry. Commission of Wisconsin v. Clicago, Burlington \& Quincy $R y$., stupra note 42 , at pp. 565-566, 42 Sup. Ct. at pp. 233-234.

${ }^{48}$ Ibid. at p. 579, 42 Sup. Ct. at p. 234 . 
first time given the power to suspend rates, and the Court characterizes the authority of the Commission thereafter in dealing with the carriers as having been made summary and substantially complete, and then goes on to say: ${ }^{47}$

"Whatever the causes, the fact was that the carrying capacity of the railroads did not thereafter develop proportionately with the growth of the country, and it became difficult for them to secure additional investment of capital on feasible terms. When the extraordinary demand for transportation arose in I9I7, the Congress and the President concluded to take over all the railroads into the management of the Federal Government, and by joint use of facilities, which the Anti-Trust Law was thought to forbid under private management, and by use of Government credit, to increase their effectiveness. This was done by appropriate legislation and executive action under the war power. From January I, I918, until March I, I920, when the Transportation Act went into effect, the common carriers by steam railroad of the country were operated by the Federal Government. Due to the rapid rise in the prices of material and labor in IgI8 and I9I9, the expense of their operation had enormously increased by the time it was proposed to return the railroads to their owners. The owners insisted that their properties could not be turned back to them by the Government for useful operation without provision to aid them to meet a situation in which they were likely to face a demoralizing lack of credit and income. Congress acquiesced in this view. The Transportation Act of 'I920 was the result. It was adopted after elaborate investigations by the Interstate Commerce Committees of the two Houses."

In another part of its opinion the Court points out ${ }^{48}$ that

"The new measure imposed an affirmative duty on the Interstate Commerce Commission to fix rates and to take other important steps to maintain an adequate railway service for the people of the United States. ... .

Intrastate rates and the income from them must play a most important part in maintaining an adequate national railway system. Twenty per cent, of the gross freight receipts of the railroads of the country are from intrastate traffic, and fifty per cent of the passenger receipts. The ratio of the gross intrastate revenue to the interstate revenue is a little less than one to three. If the rates, on which such receipts are based, are to be fixed at a substantially lower level than in interstate traffic, the share which the intrastate traffic will contribute will be proportionately less. If the railways are to earn a fixed net percentage of income, the lower the intrastate rates, the higher the interstate rates may have to be. The effective operation of the act will reasonably and justly require that intrastate traffic should pay a fair proportionate share of the cost of maintaining an adequate railway system."

The Court says that" "Section I5a confers no power on the Commission to deal with intrastate rates," but in another part of the Act, to wit, Section 13, paragraph 4, the Commission is vested with a direct

${ }^{42}$ Ibid. at pp. 582-584, 42 Sup. Ct. at pp. 235-236.

${ }^{43}$ Ibid. at pp. 585-586, 42 Sup. Ct. at p. 236.

${ }^{45} \mathrm{Ibid}$. at p. 586, 42 Sup. Ct. at p. 236. 
power to remove undue, unreasonable or unjust discrimination against interstate or foreign commerce. The Court remarks ${ }^{50}$ that

“. ... . it is impossible to escape the dovetail relation between that provision and the purpose of \$I5a. If that purpose is interfered with by a disparity of intrastate rates, the Commission is authorized to end the disparity by directly removing it, because it is plainly an undue, unreasonable, or unjust discrimination against interstate or foreign commerce, within the ordinary meaning of those words. ...

"Effective control of the one must embrace some control over the other in view of the blending of both in actual operation. The same rails and the same cars carry both. The same men conduct them. Commerce is a unit and does not regard state lines, and while, under the Constitution, interstate and intrastate commerce are ordinarily subject to regulation by different sovereignties, yet when they are so mingled together that the supreme authority, the Nation, cannot exercise complete effective control over interstate commerce without incidentâl regulation of intrastate commerce, such incidental regulation is not an invasion of state authority or a violation of the proviso. ...

"Congress as the dominant controller of interstate commerce may, therefore, restrain undue limitation of the earning power of the interstate commerce system in doing state work. ...

"It is said that our conclusion gives the Commission unified control of interstate and intrastate commerce. It is only unified to the extent of maintaining efficient regulation of interstate commerce under the paramount power of Congress. It does not involve general regulation of intrastate commerce."

The order of the District Court, granting the interlocutory injunction, was therefore affirmed.

The next case was that of the State of New York v. United States, ${ }^{51}$ involving the question whether a charter fare-limiting contract between a railroad and a state can be set aside by the provisions of the Transportation Act. It will be remembered that the Wisconsin case dealt with the statute of the State prescribing a two cent rate. The New York case raised the question whether the charter contract between the state and the New York Central, providing for a two-cent passenger rate between Albany and Buffalo, can be set aside by the order of the Commission. The state contended that if the Transportation Act permits the Interstate Commerce Commission, by an order increasing the rate to 3.6 cents, to violate the New York Central's charter contract with the state, such an act impairs the obligation of a contract and is in violation of Section ro, Article I, of the federal Constitution. The Court says ${ }^{52}$ that the section referred to "provides that no State shall .... pass any ... . law impairing the obligation of contracts, and does not in terms restrict Congress or the United States." In answer to the objection that it deprives New York and her people of property without due

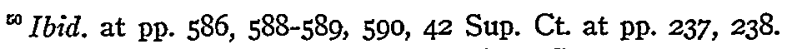

s1 (Feb. 27, I922) 257 U. S. 591, 42 Sup. Ct. 239.

${ }^{62}$ Per Taft, C. J., ibid. at p. 60I, 42 Sup. Ct. at p. 240 . Italics are the Court's. 
process of law, the Court cites ${ }^{53}$ precedent to the fact that "anything which directly obstructs and thus regulates that commerce which is carried on among the States, whether it is state legislation or private contracts between individuals or corporations, should be subject to the power of Congress in the regulation of that commerce." Therefore the Court concludes, as in the Wisconsin case, that the fact of the charter contract between the state and the New York Central is not controlling and if the lower level of intrastate rates and fares is maintained, the Commission has found that it will be discriminating against interstate commerce, in that it will require higher fares and rates in the interstate commerce of the state to secure the income for which the Commission must attempt to provide by fixing rates under the Transportation Act so as to provide the people of the United States with adequate transportation.

Then followed The New England Divisions Case, ${ }^{54}$ with a discussion of which this article closes. In that case the roads west of the Hudson River contended that, while the Commission undoubtedly had the right to fix rates adequate to earn a fair return, it did not have the right where its purpose was not to establish divisions just, reasonable and equitable, as between connecting carriers, but, in the public interest, to relieve the financial needs of the New England lines so as to keep them in effective operation. The argument was that Congress did not authorize the Commission to exercise its power to accomplish that purpose, but $\mathrm{Mr}$. Justice Brandeis, writing the opinion for a unanimous Court (as, indeed, have been all the opinions construing the Transportation Act), said in the course of the opinion: ${ }^{55}$

Upon the Commission, new powers were conferred and new duties were imposed.

"The credit of the carriers, as a whole, had been seriously impaired. To preserve for the nation substantially the whole transportation system was deemed important. . . . A general rate increase alone would not meet the situation. There was a limit to what the traffic would bear. . . . Moreover, it was not clear that the people would tolerate greatly increased rates (although no higher than necessary to produce the required revenues of weak lines) if thereby prosperous competitors earned an unreasonably large return upon the value of their properties. The existence of the varying needs of the several lines and of their widely varying earning power was fully realized. It was necessary to avoid unduly burdensome rate increases and yet secure revenues adequate to satisfy the needs of the weak carriers. To accomplish this two new devices were adopted: the group system of rate making and the division of joint rates in the public interest. Through the former, weak roads were to be helped by recapture from prosperous competitors of surplus revenues. Through the latter, the weak were to be helped by preventing needed revenue from passing to prosperous connections."

${ }^{\infty}$ Ibid. at p. 6or, 42 Sup. Ct. at p. 240, quoting Addyston Pipe \& Steel Co. v.

United States (1899) I75 U. S. 211, 230, 20 Sup. Ct. 96, 103.

" (1923) 43 Sup. Ct. 270.

cos Ibid. at p. 4. 
The opinion pointed out that the deficiency in income of the New England roads in I920 was so great as to necessitate an increase in freight revenues of 47.40 per cent if a fair return were to be secured; in Trunk Line territory, 29.76 per cent; and in Central Freight Association territory, 24.3I per cent. Instead of erecting New England into a separate rate group, which would have involved large increases in rates local to New England and might have killed New England traffic, the Commission placed New England, with the other two subdivisions of Official Classification Territory, into the Eastern Group; and ordered that freight rates in that group be raised 40 per cent. "At that rate level the revenues of the carriers in Trunk Line and Central Freight Association territories would, it was asserted, exceed by I.48 per cent what they would have received if they had been a separate group. It was estimated that the excess would be about $\$ 25,000,000$ annually. Substantially that amount (besides the additional revenue to be raised otherwise) was said to be necessary to meet the needs of the New England lines." 56

After pointing out the power granted by Section I5, Paragraph (6), of the Transportation Act, ${ }^{57}$ to the Commission to give due consideration in determining divisions to the importance to the public of the transportation services of such carriers, the Court, referring to the contention of the Trunk Lines, says: $: 58$

"The argument is that the division of a joint rate is essentially a partition of property; that the rate must be divided on the basis of the services rendered by the several carriers; that there is no difference between taking part of one's just share of a joint rate and taking from a carrier part of the cash in its treasury; and, thus, that apportionment according to needs is a taking of property without due process. But the argument begs the question. What is its just share?-It is the amount properly apportioned out of the joint rate. That amount is to be determined, not by an agreement of the parties or by mileage. It is to be fixed by the Commission; fixed at what that board finds to be just, reasonable and equitable. Cost of the service is one of the elements in rate making....

"What the Commission did was to raise the additional revenues needed by the New England lines, in part, directly, through increase of all rates 40 per cent and, in part, indirectly, through increasing their divisions on joint rates. In other words, the additional revenues needed were raised partly by a direct, partly by an indirect tax. It is not true, as argued, that the order compels the strong railroads to support the weak. No part of the revenues needed by the New England lines is paid by the western carriers. All is paid by the community pursuant to the single rate increase ordered in Ex parte 74 . If, by a single order, the Commission had raised joint rates throughout the Eastern Group 40 per cent, and, in the same order, had declared that 90 per cent of the whole increase in the joint rates should go to the New England lines (in addition to what they would receive under existing divisions),

${ }^{*}$ Ibid. at p. 7.

${ }^{57}$ Supra note I, at p. 486.

${ }^{*}$ State of New York v. United States, supra note 5I, at p. 8 et seq. 
clearly nothing would have been taken from the Trunk Line and Central Freight Association carriers, in so ordering. The order entered in Ex Parte 74 was at all times subject to change. The special needs of the New England lines were at all times before the Commission. That these needs were met by two orders instead of one is not of legal significance."

This was the gist of the Divisions Case. Other points made by the Commission, that no order could be issued until specific divisions were prescribed for each carrier, were dismissed with this statement: ${ }^{50}$

"Obviously, Congress intended that a method should be pursued by which the task, which it imposed upon the Commission, could be performed. The number of carriers which might be affected by an order of the Commission, if the power granted were to be exercised fully, might far exceed six hundred; the number of rates involved, many millions. The weak roads were many. The need to be met was urgent. To require specific evidence, and separate adjudication, in respect to each division of each rate of each carrier, would be tantamount to denying the possibility of granting relief."

As briefly, the Court dealt with the contention that the order directed a transfer of revenues of the western carriers to the New England carriers, pending a decision in the matter of divisions. The Court pointed out ${ }^{60}$ that

"To grant under such circumstances immediate relief, subject to later readjustments, was no more a transfer of revenues pending a decision, than was the like action, in cases involving general increases in rates, a transfer of revenues from the pockets of the shippers to the treasury of the carriers. That the order is not obnoxious to the due process clause, because provisional, is clear. If this were not so, most temporary injunctions would violate the Constitution."

The Court likewise sustained the Commission in dealing with the main or primary divisions of the joint rates at the Hudson River and leaving the carriers both East and West of that line to rearrange their divisions among themselves.

The scope of the opinion in the Divisions Case is as broad as, if not broader than, that contended for by the New England railroads. It justifies every common carrier, which is of importance to the public, in demanding that its rates shall so be fixed, either through increases or divisions, that it may, under honest, efficient and economical management, earn a fair return upon the value of its property held for and used in the service of transportation.

Ibid. at p. ro.

${ }^{\infty}$ Ibid. at p. I3. 